Discourse and Communication for Sustainable Education, vol. 8, no. 2, pp. 66-76, 2017

\title{
Pre-service Teachers and Self-Efficacy: A Study in Contrast
}

\author{
Tori Colson, Kelly Sparks, Gina Berridge, \\ Renee Frimming, and Clarissa Willis \\ The University of Southern Indiana, United States of America
}

\begin{abstract}
With increased emphasis on student achievement in schools, teacher education programs are challenged to meet the demand for highly effective teachers. Ensuring that preservice teachers feel confident in their ability to teach, prompted one Midwestern University to implement an extended student teaching placement. The idea behind this endeavor was two fold; first to provide future teachers a more robust and diverse classroom experience; and secondly to provide more opportunities for students to get experience in high-risk school settings. There is very limited research on the impact of year-long student teaching on a teacher's sense of efficacy. The purpose of this study was to compare the efficacy of teacher candidates placed in a year-long student teaching placement to teacher candidates placed in a traditional one semester (16 week) placement. All teacher candidates completed a 24 question Teachers' Sense of Efficacy Scale as well as nine demographic questions. The survey developed at Ohio State University by TschannenMoran and Woolfolk Hoy (2001), measures teacher attitudes towards working with students, student engagement, instructional practices, and classroom management. Specifically, the questions represent essential tasks in teaching such as assessment, differentiating lessons for individual students, dealing with students with learning challenges, repairing student understanding, and encouraging student engagement and interest. The results of the study indicated that pre-service teacher candidates in a year-long student teaching placement were more satisfied with their ability to engage students and manage classroom behavior than their counterparts in a traditional one semester placement.
\end{abstract}

Keywords: Teacher efficacy, student teaching, teacher retention, sustainability.

\section{Introduction}

Sustainability in the workforce as it relates to education means that pre-service teachers are prepared to face the realities of teaching (Williams, Edwards, Kuhel \& Lim, 2016). Multiple studies show that the teacher is a key player in the success of the individual student in the classroom (Bricker, 2000; Siverman, 2007; Pijl \& Frissen, 2009 as cited in Gedžūne, 2015 p. 96). Developing this professional state of mind has 
significant implications for teacher education programs as they attempt to identify the dispositions needed by educators in the day-to day life of a school. According to the United Nations Decade of Education for Sustainable Development Initiative, the goal of sustainability is to create a world where every child has the opportunity to benefit from a quality education. (Strode, 2013).

To help pre-service teachers maintain their interest in the profession of teaching and use those skills to help all students they teach, it is paramount that they have a strong sense of self-efficacy (Gedžūne, 2015). This is especially true for teachers who work in high-poverty, low-income schools. According to Freedman and Appleman (2009) when teacher education programs provide field experiences and coursework based in urban schools, pre-service teachers can develop a sense of empowerment which is related to retention, especially in high-poverty, low income schools. They also emphasize that when teacher education programs provide field experiences and coursework based in urban schools, pre-service teachers can develop a sense of being called into the profession, which is related to retention, especially in high-poverty, low-income schools. It is in these high-poverty, low-income settings that sustainability and the opportunity for a quality education for all children, is paramount.

\section{Pre-service Teachers and Self-efficacy}

The profession of teaching is stressful and often results in teacher burnout (Prilleltensky, Neff, \& Bessell, 2016). With this in mind, it makes sense that pre-service teachers experience stress in a school culture they do not know and with a cooperating teacher they have never met. In Bandura's (1997) classic study of pre-service teachers, he found feelings of repeated success were helpful in managing teaching stress. Although student teaching is generally associated with positive emotions for pre-service teachers (Hascher, \& Wepf, 2007), other emotions like "anxiety, nervousness, and worry" are also prevalent (Hascher \& Hagenauer, 2016, p. 22). Studies have found that student teaching prepares pre-service teachers for their role as a teacher and plays a significant role in teacher retention (Darling-Hammond, Newton, \& Wei, 2010; Gedžūne, 2015). Pre-service teachers need to feel connected and have a sense of self-efficacy for the responsibilities they face when teaching (Ryel, Bernsausen, \& van Tassell, 2001).

Self-efficacy appears to be an important motivating factor in how pre-service teachers view themselves (Arnold et al, 2011). Moulding, Stewart, and Dunmeyer (2014, p. 61) define self-efficacy as the "teachers' belief in his or her ability to successfully perform the tasks of teaching". In addition, studies have found that student achievement and self-efficacy are related (Guo, Piasta, Justice \& Kaderavek, 2010; Woolfolk-Hoy, 2005; Shoulders \& Krei, 2015). According to Woolfolk-Hoy (2005), "teachers with a strong sense of efficacy are more enthusiastic, more open to new ideas, and more willing to use complex strategies" (as cited in Moulding, Stewart \& Dunmeyer, 2014, p. 61). The same study found that teacher's self-efficacy is related to student achievement.

\section{Self-Efficacy and Teacher Mentors}

In a study by Woolfolk-Hoy (2005), a positive relationship was found between a pre-service teacher's self-efficacy and the support they receive from their teacher mentor. (Hamman et al., 2006). According to the Hamman study, support was defined by both 
the amount of time that the teacher mentor worked one-on-one with the pre-service teacher, as well as, the type of support the teacher received.

Bonnie Bernard (1995) found pre-service teachers need to have opportunities for participation that are meaningful and according to $\mathrm{He}(2009)$ pre-service teachers must develop strategies to maintain their enthusiasm for teaching. It stands to reason that positive experiences for first year teachers are linked to quality mentoring experiences. According to Ambrosetti and Dekkers (2010), mentoring usually occurs during student teaching in most pre-service education programs. The time the pre-service teacher spends in the classroom often varies in length therefore; the types of mentoring relationships that are formed may be significantly different.

According to Lai (2005) "mentoring plays an important role in enhancing novice teachers' opportunities to learn. (as cited in Ambrosetti and Dekkers, 2010, p. 44). Lave and Wenger (1991) identified a community of practice consisting of old and new members who share a common passion. New members are those members that gain valuable experience and knowledge when interacting with others and modeling older members. When this practice is applied to student teaching, it is believed that the new members (the pre-service teachers) and the older members (teacher mentors) interact for a common purpose. The senior members are considered those who have gained knowledge and have more experience teaching and the new members are those students who have little to no experience teaching. Ideally, this positive social interaction between the two groups help the pre-service teachers (new members) overcome any barriers because they would have access to the knowledge and experience provided by the more seasoned teacher.

Some studies have found that new teachers often begin their first job with a distorted view of what constitutes 'good teaching' (de Jong et al., 2013). The discrepancy between what pre-service teachers perceived would happen their first year of teaching and what actually does happen is referred to as "reality shock" which results in high turnover and low retention of beginning teachers (OECD, 2005; Sinclair, 2008). Kim and Cho (2012) define reality shock for teachers as "a gap between what they learned in the teacher education program and the reality that they may face during the first year of teaching, with respect to the work of teaching the context in which teaching will occur" (p. 68). Studies such as Ingersoll and Smith (2004) and Johnson and Birkeland (2002) suggest that new teachers with a high sense of self-efficacy will remain in the profession. According to Klassen and his colleagues (2013), self-efficacy beliefs of pre-service teachers "provide a protective shield against low commitment and teacher attrition" (p. 1303). Low commitment to the teaching profession during this first year has been linked to decisions to leave the profession in the first five years (Rots et al., 2007). Teachers with self-efficacy would not be anxious or fear unexpected challenges because they believe they could deal with those situations (Kim \& Cho, 2012).

\section{Self-Efficacy and Effective Teacher Education Programs}

"The necessary qualifications by which a pre-service teacher will learn to become an effective teacher in the future are attained through teacher education programs" (Temiz \& Topcu, 2013, p. 1435). Characteristics of teacher education programs like length of field placements, the relationship between the university and the district where the teacher-candidate is placed, the school's climate and the overall acceptance of the pre-service teacher within that climate, can have an effect on the learning process and the success of that candidate (Hascher \& Kittinger, 2014). 
According to Klassen et al. (2013) teacher education programs should address the stress experienced by pre-service teachers and focus on developing strategies to manage that stress. Kim and Cho (2012) believe that effective teacher education programs should prepare students to be resilient and have high self-efficacy by building successful teaching cohorts so pre-service teachers can share their teaching experiences and, address the issue of reality shock.

A study of teacher education programs by Ronfeldt, Schwartz and Jacob (2014) suggests that teacher education programs can improve pre-service teacher preparedness and impact the future success of those pre-service teachers by increasing the time they spend in the classroom. Another study by Hung and Waxman (2009) suggests that the school where student teachers are placed is important and matters in terms of satisfaction of the student teacher and that future teacher's commitment to the profession. This is important because, according to Ciani, Summers and Easter (2008), a supportive environment in which a pre-service teacher experiences a positive teacher community may help to strengthen their self-efficacy. According to Knoblauch and Chase (2015) even though research indicates that teacher education programs must have multiple field placements in diverse settings like high minority, high-poverty, inner city schools, there is little evidence of pre-service teachers' sense of self-efficacy as it relates to these settings.

A mid-western university in collaboration with a local school district, developed a year-long student teaching program designed to help pre-service teachers develop relationships that would lead to a stronger sense of efficacy. Teacher candidates were placed in high-poverty low-income schools where additional support was needed. "Teach Now: Transform Tomorrow", a pilot program for 15 pre-service teacher candidates was designed so that candidates would start at the beginning of the school year and stay in the same classroom through early May. Pre-service teachers applied to be part of the pilot and were selected based on interviews. Principals then matched each pre-service teacher with a mentor teacher in their respective schools.

This program differs from a traditional student teaching experience in several ways: First a traditional sixteen-week student teaching experience does not allow for preservice teachers to be involved across an entire school year and secondly, this program allowed for continuity of services for K-12 students enrolled in high-poverty schools. It was believed that this consistency of placement (being there throughout an entire school year) would allow for stronger relationships with students and provide the teacher candidates with a more realistic view of a public-school environment.

\section{Research Methodology}

\section{Design and Sample}

An exploratory study was conducted to compare the efficacy in teacher candidates placed in a year-long student teaching placement and teacher candidates placed in a traditional one semester (16 week) placement.

A total of 144 undergraduate teaching candidates at a mid-sized, public, NCATE accredited, university in the Midwest participated in this study. Each participant had completed the requisite teacher preparation and content area coursework, finished all field observation experiences, and participated in pre-student teaching practicum teaching in the public schools and were fully eligible to student teach. Teacher candidates in the traditional one semester student teaching placement (K-12) were asked to participate 
after completion of their student teaching. Surveys were completed in fall and in spring by those teacher candidates who participated in a traditional one semester placement in both elementary and secondary settings. Teacher candidates in the year-long student teaching placement were asked to participate at the completion of their year-long student teaching placement. All teacher candidates completed the 24 question Teachers' Sense of Efficacy Scale as well as nine demographic questions.

\section{Instrumentation}

The Teachers' Sense of Efficacy Scale (TSES) developed at Ohio State University by Tschannen-Moran and Woolfolk Hoy (2001) was selected for this project. This survey measures teacher attitudes towards: working with students, student engagement, instructional practices, and classroom management.

The questions are designed to depict distinct areas associated with a teacher's role. Specifically, the questions represent essential tasks in teaching such as assessment, differentiating lessons for individual students, dealing with students with learning challenges, repairing student understanding, and encouraging student engagement and interest (Tschannen-Moran \& Woolfolk Hoy, 2001).

The long form of TSES which consists of 24 questions ranked on 9-point Likert scale was used. The responses ranged from 1 - nothing, 5 - some influence, to 7 - quite a bit, and 9 - a great deal. Sample questions include: To what extent can you use a variety of assessment strategies? How much can you do to control disruptive behavior in the classroom? How much can you do to get students to believe they can do well in schoolwork? For reliability data see Table 1 .

Table 1

Reliabilities of the Teachers' Sense of Efficacy Scale

\begin{tabular}{lccc}
\hline & \multicolumn{3}{c}{ Long form } \\
\hline MSES (OSTES) & 7.10 & .94 & .94 \\
\hline Engagement & 7.30 & 1.10 & .87 \\
\hline Instruction & 7.30 & 1.10 & .91 \\
\hline Management & 6.70 & 1.10 & .90 \\
\hline
\end{tabular}

\section{Results}

An independent samples $t$ test was conducted to evaluate the impact of year-long student teaching on the efficacy of teacher candidates in student engagement, instructional practices, and classroom management are shown in Table 2. Levene's test evaluates the assumption that the population variances for the two groups are equal. The variances are very similar and, consequently, the standard $t$ test and the $t$ test for unequal variances yield comparable results. Since the variances for the two groups are not different, but the sample sizes are different, the $t$ value that does not assume equal variances will be reported, thereby avoiding the homogeneity of variances assumption. Teacher candidates in a year-long student teaching placement reported significantly higher levels of efficacy in student engagement than teacher candidates in a one semester student teaching place- 
ment. Pre-service teacher candidates in a year-long student teaching placement feel more confident in their ability to engage students than those that only had a traditional teaching placement.

Similarly, teacher candidates in a year-long student teaching placement reported significantly higher levels of efficacy in classroom management than teacher candidates in a one semester student teaching placement. The year-long teacher candidates felt very confident in their classroom management skills versus the one semester teacher candidates. Conversely, teacher candidates in a year-long student teaching placement and teacher candidates in a one semester student teaching placement showed no significant difference in their efficacy in instructional practices. Both groups of teacher candidates felt very efficacious in their instructional practices.

Table 2

Differences in Efficacy for Teacher Candidates Based on Student Teaching Placement

Yearlong student One semester

teaching placement student teaching

\begin{tabular}{lcccccc}
\multicolumn{2}{c}{$(N=15)$} & placement $(N=59)$ & & \\
\hline Variable & $M$ & $S D$ & $M$ & $S D$ & $T$ & $D$ \\
\hline Efficacy in student engagement & 7.96 & .69 & 7.52 & .78 & $-2.13^{*}$ & $-.28^{*}$ \\
\hline Efficacy in instructional practices & 7.98 & .72 & 7.62 & .77 & -1.68 & -.23 \\
\hline Efficacy in classroom management & 8.18 & .47 & 7.56 & .80 & $-3.82^{*}$ & $-.42^{* *}$ \\
\hline
\end{tabular}

$* p<.05, * p<.01$.

Table 3 represents all elementary education majors that participated in student teaching. The authors looked at the difference between teacher candidates that were elementary majors that did their student teaching in the year-long program and teacher candidates that were elementary majors that did their student teaching in a traditional, one semester, student teaching placement. When looking at their efficacy in student engagement and instructional practices, no significant difference between the two groups of teacher candidates was found. Conversely, teacher candidates in the year-long student teaching placement reported significantly higher means in classroom management than the teacher candidates with the one semester student teaching placement.

Table 3

Differences in Efficacy for Teacher Candidate Based on Student Teaching Placement

\begin{tabular}{|c|c|c|c|c|c|c|}
\hline \multirow[b]{2}{*}{ Variable } & \multicolumn{2}{|c|}{$\begin{array}{l}\text { Yearlong student } \\
\text { teaching placement } \\
\qquad(N=15)\end{array}$} & \multicolumn{2}{|c|}{$\begin{array}{c}\text { One semester } \\
\text { student teaching } \\
\text { placement }(N=22)\end{array}$} & \multirow[b]{2}{*}{$T$} & \multirow[b]{2}{*}{$D$} \\
\hline & $M$ & $S D$ & $M$ & $S D$ & & \\
\hline Efficacy in student engagement & 7.96 & .69 & 7.56 & .72 & -1.70 & .58 \\
\hline Efficacy in instructional practices & 7.98 & .72 & 7.63 & .81 & -1.34 & .22 \\
\hline Efficacy in classroom management & 8.18 & .47 & 7.75 & .70 & $-2.07 *$ & $.34 \%$ \\
\hline
\end{tabular}

$* p<.05$

The mean efficacy scores for teacher candidates in a year-long student teaching placement and traditional, one semester, secondary student teaching placement is represented in Table 4. The authors found significant differences in the efficacy in student 
engagement, instructional practices, and classroom management between the groups. Yearlong student teaching placement candidates reported significantly higher in all three areas as compared to secondary teacher candidates in the traditional, one semester, student teaching placement.

Table 4

Differences in Efficacy for Teacher Candidates Based on Student Teaching Placement

\begin{tabular}{lcccccc}
\hline & $\begin{array}{c}\text { Yearlong student } \\
\text { teaching placement } \\
(N=15)\end{array}$ & $\begin{array}{c}\text { One semester } \\
\text { secondary student } \\
\text { teaching placement } \\
(N=21)\end{array}$ \\
\hline Variable & $M$ & $S D$ & $M$ & $S D$ & $T$ & $D$ \\
\hline Efficacy in student engagement & 7.96 & .69 & 7.33 & .86 & $-2.32^{*}$ & $.37^{*}$ \\
\hline Efficacy in instructional practices & 7.98 & .72 & 7.45 & .83 & $-2.01^{*}$ & $.34^{*}$ \\
\hline Efficacy in classroom management & 8.18 & .47 & 7.15 & .93 & $-4.32^{* *}$ & $.57^{* *}$ \\
\hline
\end{tabular}

$* p<.05, * p<.01$.

\section{Discussion}

Results of this study suggest that teacher candidates in a year-long student teaching placement were more efficacious in their ability to engage students and manage classroom behaviors than pre-service teacher candidates in a traditional one semester placement. It could be said that this is a result of their extended stay in the classroom. None the less, self-efficacy is crucial to what teachers believe, how they feel, how they motivate themselves, what activities they do in the classroom, and also the effort and persistence they put into the profession (Pajares, 1997; Pintrich \& Schunk, 2002). By starting at the beginning of the school year and working with the same students throughout the year, the year-long teacher candidates felt very confident in their ability to manage behavior in the classroom. The year-long teacher candidates had more time to learn how to engage students, as well as more time to get to know the school culture, and thus feel more confident in managing behavior. This correlates with the study by Tschannen-Moran, and Woolfolk-Hoy (1998) that reported that teacher efficacy was also a predictor of classroom management skills like planning and organization.

Moreover, both groups of teacher candidates had a strong sense of efficacy in their ability to use effective instructional practices in the classroom. Not only do pre-service teacher candidates report a higher sense of efficacy, pre-service teacher candidates that participated in a year-long student teaching placement perceive themselves more prepared to teach; therefore, ultimately providing school districts with new teachers that are highly efficacious in student engagement, instructional practices, and classroom management. In addition a year of focused teaching experience in a classroom setting made the yearlong teacher candidates more prepared to teach. This is important because teachers with a high sense of efficacy tend to be flexible in their approaches to different teaching methods (Weiner, 2003), show great commitment to the profession (Coladarci, 1992) and work with students longer, especially those who have behavior and/or learning problems (Ashton, \& Webb, 1986).

Furthermore, when looking at the difference between the year-long teacher candidates and teacher candidates placed in a traditional, one semester, secondary placement, the 
year-long teacher candidates were more efficacious in all three areas; student engagement, instructional practices, and classroom management. Yearlong teacher candidates spend significantly more time in the classroom during their student teaching placement and receive more mentoring from the supervising teacher than those in the traditional student teaching placement. Additionally, secondary candidates only minor in education and major in the content area at this university. The difference in the amount of education course work could also impact the efficacy of the teacher candidates at the secondary level.

Research has shown a link between teacher efficacy and student achievement (Goddard, Hoy, \& Hoy, 2000; Tschannen-Moran \& Barr, 2004). Tschannen-Moran \& WoolfolkHoy, 2001 found it to be a powerful predictor of achievement in students. While these results are not indicative of student achievement, school leaders who hire new teachers with a strong sense of efficacy expect that these teachers will be more effective than their counterparts who have far less classroom experience. In return, when school districts are hiring new teachers that demonstrate a high sense of efficacy, recruitment from higher education institutions that are cultivating these new teachers will be impacted. Thus, the effect of a pre-service teacher candidate with a year-long student teaching placement can and will be measured by employability skills. These employability skills are often associated as traits of effective teachers. Yearlong student teachers, with a high sense of efficacy in student engagement and classroom management, may be considered for employment more than their peers who did not have a year-long student teaching placement. There is a need for continual scholarly interest in the field of teacher self-efficacy as accountability for effective teachers across the nation continues and as the focus on teacher quality is ever-present in K-12 school districts and higher education institutions.

\section{Implications and Future Research}

The implications of this study relate to both teacher education and K-12 school districts. This study provides quantitative information about the perceptions of preservice teachers' efficacy in student engagement, instructional practices, and classroom management who are placed in a year-long student teaching placement versus a traditional one semester placement. A higher education initiative in teacher education could be designed so that all pre-service teacher candidates are placed in a year-long student teaching placement. In addition, providing professional development opportunities in the areas of student engagement and classroom management to pre-service teacher candidates could dramatically increase that teacher candidates' efficacy in those areas.

The design of secondary education courses could be modified to include more course work that will affect how teacher candidates learn classroom management, instructional strategies, and student engagement. Further research is necessary to determine the specific attributes of the year-long student teaching placement that would be most effective in promoting this type of reform in higher education.

More research is needed to determine if a year-long student teaching placement cultivates highly efficacious teachers. Especially, investigating qualitatively the difference between elementary school placements versus secondary school placements and why there is a difference in their efficacy. Qualitative studies to determine which elements of a yearlong student teaching placement are most effective and impactful on future teaching success are also needed. Using this information teacher preparation programs can design quality student teaching placements which result in teachers who are more prepared for the 'reality' of teaching. 


\section{References}

Ambrosetti, A., \& Dekkers, J. (2010) The Interconnectedness of the roles of mentors and mentees in pre-service teacher education mentoring relationships. Australian Journal of Teacher Education, 35, 42-55.

Arnold, K. H., Hascher, T., Messner, R., Niggli, A., Patry, J. L., \& Rahm, S. (2011). Empowerment durch Schulpraktika [Empowerment through student teaching]. Bad Heilbrunn: Klinkgardt.

Ashton, D., \& Webb, R. B. (1986). Making a difference: Teachers' sense of efficacy and student achievement. NY: Longman.

Bandura, A. (1997). Self-efficacy: The exercise of control. New York: Freeman.

Bernhard, B. (1995). Fostering resiliency in kids. Educational Leadership, 31, 44-48.

Bricker, D.(2000). Inclusion: How the scene has changed. Topics in Early Childhood Special Education, 20(1), 14-19.

Ciani, K. D., Summers, J. J., \& Easter, M. A. A. (2008). Top-down analysis of high school teacher motivation. Contemporary Educational Psychology, 33, 533-560.

Coladarci, T. (1992). Teachers' sense of efficacy and commitment to teaching. Journal of Experimental Education, 60, 323-337.

deJong, R., Mainhard, T., Tartwijk, J., Veldman, I.Verloop, N., \& Wubbels. T. (2013). How pre-service teachers' personality traits, self-efficacy, and discipline strategies contribute to the teacher-student relationship. Educational Psychology, 84, 294-310.

Darling-Hammond, L., Newton, X., \& Wei, R. (2010). Evaluating teacher education outcomes: a study of the Stanford Teacher Education Programme. Journal of Education for Teaching, 36(4), 369-388.

Freedman, S. W., \& Appleman, D. (2009). "In it for the long haul”: How teacher education can contribute to teacher retention in high-poverty urban schools. Journal of Teacher Education, 60, 323-337.

Gedžūne, G. (2015). Awakening pre-service teachers to children's social exclusion in the classroom. Discourse and Communication for Sustainable Education, 6, 95-109.

Goddard, R. D., Hoy, W. K., \& Hoy, A. W. (2000). Collective teacher efficacy: Its meaning, measure, and impact on student achievement. American Educational Research Journal, 37(2), 479-507.

Guo, Y., Piasta, S. B., Justice, L. M., \& Kaderavek, J. N. (2010). Relations among preschool teachers' self-efficacy, classroom quality, and children's language and literacy gains. Teaching and Teacher Education, 26(4), 1094-1103.

Hamman, D., Olivarez, A., Jr., Lesley, M., Button, K., Chan, Y., Griffith, R., \& Elliot, S. (2006). Pedagogical influence of interaction with cooperating teachers on efficacy beliefs of student teachers. The Teacher Educator, 42, 14-29.

Hascher, T., \& Hagenauer, G. (2016). Openness to theory and its importance for preservice teachers' self-efficacy, emotions, and classroom behavior in the teaching practicum. International Journal of Educational Research, 77, 15-25.

Hascher, T., \& Kittinger, C. (2014). Learning processes in student teaching. Analyses from a study using learning diaries. Schulpraktika in der Lehrerbildung [School practices in teacher education], 221-235.

Hascher, T., \& Wepf, L. (2007). Lerntagebücher im Praktikum von Lehramtsstudierenden [Learning Diaries in the Internship of Student Teachers]. Empirische Pädagogik. [Journal on Theory and Practice of Educational Research] 21(2), 101-118. 
He, Y. (2009) Strength-based mentoring in pre-service teacher education: a literature review. Mentoring and Tutoring: Partnership in Learning, 17, 263-275.

Hung, S.L., \& Waxman, H, C. (2009). The association of school environment to student teacher's satisfaction and teaching commitment. Teaching and Teacher Education, 25, 235-243.

Ingersoll, R. M., \& Smith, T.M. (2004). Do teacher induction and mentoring matter? NASSP Bulletin, 88, 28-40.

Johnson, R. F., \& Birkeland, K. W. (2002). Integrating shear quality into stability test results. In J.R. Stevens (Eds.) Proceedings of the 2002 International Snow Science Workshop (pp. 508-513). Penticton, BC. Retrieved from http://www.fsavalanche. org/NAC/techPages/articles/02_ISSW_shear_quality.pdf

Kim, H., \& Cho, Y. (2012). Pre-service teachers' motivation, sense of teaching efficacy, and expectation of reality shock. Asia-Pacific Journal of Teacher Education, 42(1), 67-81.

Klassen, R., Wilson, E., Siu, A., Hannok, W., Wong, M., Wongsri, N., Sonthisap, P., Pibulchol, C., Buranachaitavee, Y., \& Jansem, A. (2013). Pre-service teachers' work stress, self-efficacy and occupational commitment in four countries. European Journal of Psychology of Education, 28, 1289-1309.

Knoblauch, D., \& Chase, M.A. (2015). Rural, suburban, and urban schools: The impact of school setting on the efficacy beliefs and attributions of student teachers. Teacher and Teacher Education, 45, 104-114.

Lai, E. (2005). Mentoring for in-service teachers in a distance teacher education programme: views of mentors, mentees and university teachers. Paper presented at the Australian Association for Research in Education International Education Research Conference, Parramatta.

Lave, J., \& Wenger, E. (1991) Situated learning: legitimate peripheral participation Cambridge: Cambridge University Press.

Moulding, L., Stewart, W., \& P., \& Dunmeyr, M. (2014). Pre-service teachers' sense of efficacy: Relationship to academic ability, student teaching placement characteristics, and mentor support. Teaching and Teacher Education, 41, 60-66.

OECD (2005). Teachers matter: Attracting, developing and retaining effective teachers. Paris: OECD.

Pajares, F. (1997). Current directions in self-efficacy research. In M. L. Maehr, \& P. R. Pintrich (Eds.), Advances in motivation and achievement. (pp. 1-49). Greenwich: CT: JAI Press.

Pijl,S. J., \& Frissen, P. H. A. (2009). What policymakers can do to make education inclusive Educational Management Administration \& Leadership, 37(3), 366-377.

Pintrich, P. R., \& Schunk, D. H. (2002). Motivation in education: Theory, research, and applications. Columbus, $\mathrm{OH}$ : Merrill.

Prilleltensky, I., Neff, M., \& Bessell, A. (2016). Teacher stress: What it is, why it's important, how it can be alleviated. Theory Into Practice, 55(2), 104-111.

Ronfeldt, M., Schwartz, N., \& Jacob, B. (2014). Does pre-service preparation matter? Examining old questions in new ways. Teachers College Record, 116(10), 1-46.

Rots, I., Aelterman, A., Vlerick, P., \& Vermeulen, K. (2007). Teacher education, graduates' teaching commitment and entrance into the teacher profession. Teacher and Teacher Education, 23, 543-556. 
Ryel, R., Bernsausen, D., \& van Tassell, F. (2001) Advocating resiliency through wellness. Paper presented at the 2001 Association of Teacher Educators annual meeting. New Orleans: LA.

Shoulders, T. L., \& Krei, M. S. (2015). Rural high school teachers' self-efficacy in student engagement, instructional strategies, and classroom management. American Secondary Education, 44(1), 50-61.

Silverman, J. C. (2007). Epistemological beliefs and attitudes toward inclusion in preservice teachers. Teacher Education and Special Education: The Journal of the Teacher Education Division of the Council for Exceptional Children, 30(1), 42-51.

Sinclair, C. (2008). Initial and changing student teacher motivation and commitment to teaching. Asia-Pacific Journal of Teacher Education, 36(2), 79-104.

Strode, A. (2013). Participatory action research for development of prospective teacher's professionality during their pedagogical practice. Discourse and Communication for Sustainable Education, 4, 80-90.

Temiz, T., \& Topcu, M. S. (2013). Pre-service teachers' teacher efficacy beliefs and constructivist-based teaching practice. European journal of psychology of education, 28(4), 1435-1452.

Tschannen-Moran, M., \& Barr, M. (2004). Fostering student learning: The relationship of collective teacher efficacy and student achievement. Leadership and Policy in Schools, 3(3), 189-209.

Tschannen-Moran, M., \& Woolfolk-Hoy, A. (2001) Teacher efficacy: Capturing an elusive construct. Teaching and Teacher Education, 17, 783-805.

Tschannen-Moran, M., \& Woolfolk-Hoy, A. (1998) Teacher efficacy: It's meaning and measure. Review of Educational Research, 68, 202-248.

Weiner, L. (2003). Why is classroom management so vexing to urban teachers? Theory into Practice, 42(4), 305-312.

Williams, D., Edwards, B., Kuhel, K., \& Lim, W. (2016). Culturally responsive dispositions in prosepective mathematics teachers. Discourse and Communication for Sustainable Education, 7(2), 17-33.

Woolfolk-Hoy, A. E. (2005). What predicts student teacher self-efficacy? Academic Exchange Quarterly, 9(4), 123-127.

Woolfolk-Hoy, A., Hoy, W. K., \& Davis, H. (2009). Teachers' self-efficacy beliefs. In K. Wentzel \& A. Wigfield (Eds.), Handbook of motivation in schools (pp 627654). Mahwah, NJ: Eribaum.

Correspondence concerning this paper should be addressed to Dr. Clarissa Willis, Associate Professor, Teacher Education, University of Southern Indiana, 8600 University Boulevard, Evansville, Indiana 47712, The United States of America. Email: cwillis6@usi.edu 